\title{
KONSEP PERLINDUNGAN HUKUM ATAS PRIVASI DAN DATA PRIBADI DIKAITKAN DENGAN PENGGUNAAN CLOUD COMPUTING DI INDONESIA
}

\author{
Sinta Dewi \\ Fakultas Hukum Universitas Padjadjaran \\ Email:sintadewirosadi@yahoo.com
}

\begin{abstract}
The increasing use of internet technology has spawned new challenges to the protection of privacy and personal data, especially with the increasing practice of collection, use and dissemination of personal data of a person. The lack of specific instruments and regulations will cause of the weakness of the privacy and data personal protection mechanism, especially in the use of cloud computing technology. Cloud computing is a technology that uses the internet and central remote servers to maintain or manage user data. It allows users to use applications without installation so that personal files can be accessed anywhere and anytime through internet access. This technology enables efficiencies by centralizing storage, processing and data memory. However, on the other hand, cloud computing has raised a new legal issue is how could the personal data of the user of cloud computing be protected from a wide range of abuses by the provider of cloud computing and the third party. This legal issue become very significant because if a personal data of the user of cloud computing is misused by the provider or the third party, then it is contrary to human rights, namely the protection of privacy and personal data which has been protected by international, regional, and national instruments. So far, Indonesia has not been having regulation that specifically protect its citizens from the personal data abuse whether committed by governments, private companies or individuals. Therefore, this study aims to create the concept of adequate regulation in order to provide protection for user of cloud computing services in Indonesia.
\end{abstract}

Keywords: protection, privacy, personal data, cloud computing.

\begin{abstract}
Abstrak
Meningkatnya pemanfaatan teknologi internet melahirkan tantangan baru dalam perlindungan atas privasi dan data pribadi, terutama dengan semakin meningkatnya praktik pengumpulan, pemanfaatan dan penyebaran data pribadi seseorang. Ketertinggalan instrumen dan regulasi menjadi salah satu pemicu lemahnya mekanisme proteksi terhadap privasi dan data pribadi khususnya dalam penggunaan teknologi cloud computing. Cloud computing adalah teknologi yang menggunakan internet dan server pusat yang jauh untuk menjaga atau mengelola data pengguna. Cloud computing membantu pengguna untuk menggunakan aplikasi tanpa melakukan instalasi sehingga file pribadi dapat diakses di manapun dan kapanpun melalui akses internet. Teknologi ini memungkinkan efisiensi dengan memusatkan penyimpanan, pemrosesan dan memori data. Namun demikian, di sisi lain, cloud computing telah menimbulkan permasalahan hukum baru yaitu bagaimana data pribadi pengguna cloud computing terlindungi dari berbagai macam pengungkapan dan pendistribusian oleh penyedia jasa cloud computing terhadap pihak ketiga. Permasalahan hukum ini menjadi sangat signifikan karena jika data pribadi seseorang disalahgunakan oleh pihak penyedia data atau pihak ketiga, maka hal ini bertentangan dengan hak dasar manusia yaitu perlindungan terhadap privasi dan data pribadi seseorang yang telah dilindungi oleh instrumen internasional, regional dan nasional. Indonesia hingga saat ini belum memiliki regulasi yang secara khusus melindungi warga negara dari praktik pemanfatan data pribadi yang sewenang wenang, baik yang dilakukan oleh pemerintah, perusahaan swasta maupun individu. Oleh sebab itu, penelitian ini bertujuan untuk menciptakan konsep pengaturan yang memadai dalam rangka memberikan perlindungan bagi pengguna jasa cloud computing di Indonesia.
\end{abstract}

Kata kunci: perlindungan, privasi, data pribadi, cloud computing. 


\section{A. Pendahuluan}

Perkembangan teknologi informasi dan komunikasi yang melaju dengan pesat telah menimbulkan berbagai peluang dan tantangan. Salah satu bidang yang dipengaruhi oleh perkembangan teknologi informasi adalah terjadinya interaksi yang aktif antara individu dengan pihak penyedia jasa informasi. Berbagai sektor kehidupan telah memanfaatkan sistem informasi, seperti bidang perdagangan (e-commerce), transportasi, industri, pariwisata, bidang pemerintahan (e-government) dan industri keuangan (e-payment). Cakupan dan sistem teknologi informasi meliputi pengumpulan (collect), penyimpanan (store), pemroses, produksi dan pengiriman, dari dan ke industri atau masyarakat secara cepat dan efektif (Sinta Dewi, 2015: 165).

Informasi telah melahirkan suatu etika baru bahwa setiap pihak yang mempunyai informasi memiliki naluri yang senantiasa mendistribusikan kepada pihak lain (Abdul Raman Saad, 2005: 1-2). Dalam perkembangan ekonomi yang modern seperti sekarang ini, informasi, termasuk juga data pribadi, merupakan aset yang sangat berharga karena memiliki nilai ekonomi yang tinggi sehingga banyak dimanfaatkan oleh kalangan bisnis. Keadaan ini dikenal dengan istilah digital dossier, yaitu pengumpulan informasi tentang seseorang dalam jumlah yang banyak dengan menggunakan teknologi digital yang diawali sejak awal tahun 1970 dengan menggunakan komputer hingga sekarang dengan menggunakan internet. Salah satu perkembangan teknologi informasi adalah revolusi di bidang teknologi komputer yang dapat menyimpan data dalam jumlah yang besar yang dinamakan cloud computing atau komputasi awan, yang merupakan gabungan pemanfaatan teknologi komputer ('komputasi') dan pengembangan berbasis internet ('awan') (http://netindonesia. net/blogs/ianhutomo/archive/2011/07/14/apa-itucloud-computing.aspx, diakses tanggl 10 Juni, 2012). Cloud computing adalah teknologi yang menggunakan internet dan server pusat yang jauh untuk menjaga atau mengelola data pelanggan. Cloud computing membantu konsumen dan pebisnis untuk menggunakan aplikasi tanpa melakukan instalasi, mengakses file pribadi mereka di manapun dengan menggunakan akses internet. Teknologi ini memungkinkan efisiensi dengan memusatkan penyimpanan, pemrosesan dan memori data (ACLU, 2010: 1-4). Disamping itu, kelebihan cloud computing yang lain adalah ia dapat meningkatkan produktifitas bisnis pelanggan sehingga pelanggan tidak perlu lagi mengeluarkan investasi dan biaya untuk membangun pusat data. Selain itu, pemanfaatan cloud computing dapat dilakukan secara cepat dan mudah dan memiliki mobilitas yang sangat tinggi karena dapat diakses melalui internet (ACLU, 2010: 1-4).

Berdasarkan penelitian yang telah dilakukan oleh para ahli menunjukkan bahwa pada tahun 2014, bisnis cloud computing telah mencapai nilai 60 juta hingga 80 juta dolar Amerika Serikat atau sekitar $10 \%$ dari pemasaran industri informasi dan teknologi secara keseluruhan (Paolo Balboni, 2010: 1-3). Hal ini menunjukkan bahwa bisnis cloud computing menjadi salah satu bisnis yang menjanjikan di masa sekarang dan yang akan datang. Beberapa perusahaan yang menggunakan teknologi cloud computing diantaranya adalah yahoo email dan google email. Di Indonesia, salah satu perusahaan yang bergerak di bidang telekomunikasi yang telah menggunakan cloud computing adalah PT. Telkom sebagai pemain utama di bidang layanan data center. Cloud computing yang dikelola PT. Telkom telah dimanfaatkan untuk berbagai sektor industri seperti pertanian, pendidikan, kesehatan, keuangan dan perbankan, hotel, transportasi, dan pertambangan (http://www.telkomcloud.com/ enterprise/banking/, diakses tanggal 12 Juni, 2012). Menurut hasil penelitian yang dilakukan oleh Frost \& Sullivan, pertumbuhan pendapatan rata-rata layanan cloud computing di Indonesia diperkirakan sebesar $48 \%$ per tahun hingga tahun 2014. Segmen layanan "infrastructure as a service" atau data center tumbuh paling pesat di antara layanan cloud computing lainnya dengan pertumbuhan sekitar 55,9\% (http:// www.indonesiafinancetoday.com/read/16131/ Pendapatan-Cloud-Computing-di-IndonesiaTumbuh-48-hingga-2014, diakses tanggal 13 Juni 2015). Selanjutnya, masih di Indonesia, nilai bisnis cloud computing pada tahun 2015 diperkirakan menembus angka Rp. 3,6 Trilyun atau naik sekitar 70\% dibandingkan tahun 2014 dan pasar cloud computing diperkirakan masih akan tumbuh $20 \%$ dengan kenaikan pada segmen korporasi sehingga akan menjadikan Indonesia sebagai salah satu negara yang menerapkan cloud computing tertinggi di Asia-Pasific (http:// fianka73.blogspot.com/2013/06/di-indonesiabisnis-cloud-computing.html, diakses tanggal 1 November 2015).

Penggunaan cloud computing memiliki banyak manfaat. Selain mengurangi biaya operasional karena pelanggan hanya akan membayar jasa yang digunakan, juga pelanggan tidak perlu menyediakan infrastruktur dan perangkat lunak ketika akan menggunakan aplikasi cloud computing, karena semua itu telah disediakan oleh provider dari jarak jauh dengan 
menggunakan media internet. Selain itu, karena sifatnya yang sangat mobile (based on internet), maka para pelanggan dapat mengaksesnya setiap saat dan di manapun berada sehingga akan lebih efisien.

Beberapa contoh aktivitas keseharian yang menggunakan cloud computing dewasa ini antara lain web-based email seperti yang selama ini dilakukan melalui Yahoo and Microsoft Hotmail; menyimpan foto dalam Google Picassa; aplikasi spreadsheet applications dalam Zoho; online computer backup services seperti dalam Mozy; file transfer services dalam YouSendlt; online medical records storage dalam Microsoft HealthVault; aplikasi untuk social networking seperti Facebook (https://www.privacyrights.org/ar/cloud-computing. htm, diakses tanggal 10 September 2013). Sedangkan perusahaan-perusahaan internasional yang merupakan pemain utama cloud computing adalah Google, Yahoo, Microsoft, Yahoo, Amazon, Salesforce, Sun Microsystems, Oracle, EMC.

\section{Gambar 1: Beberapa manfaat cloud computing}

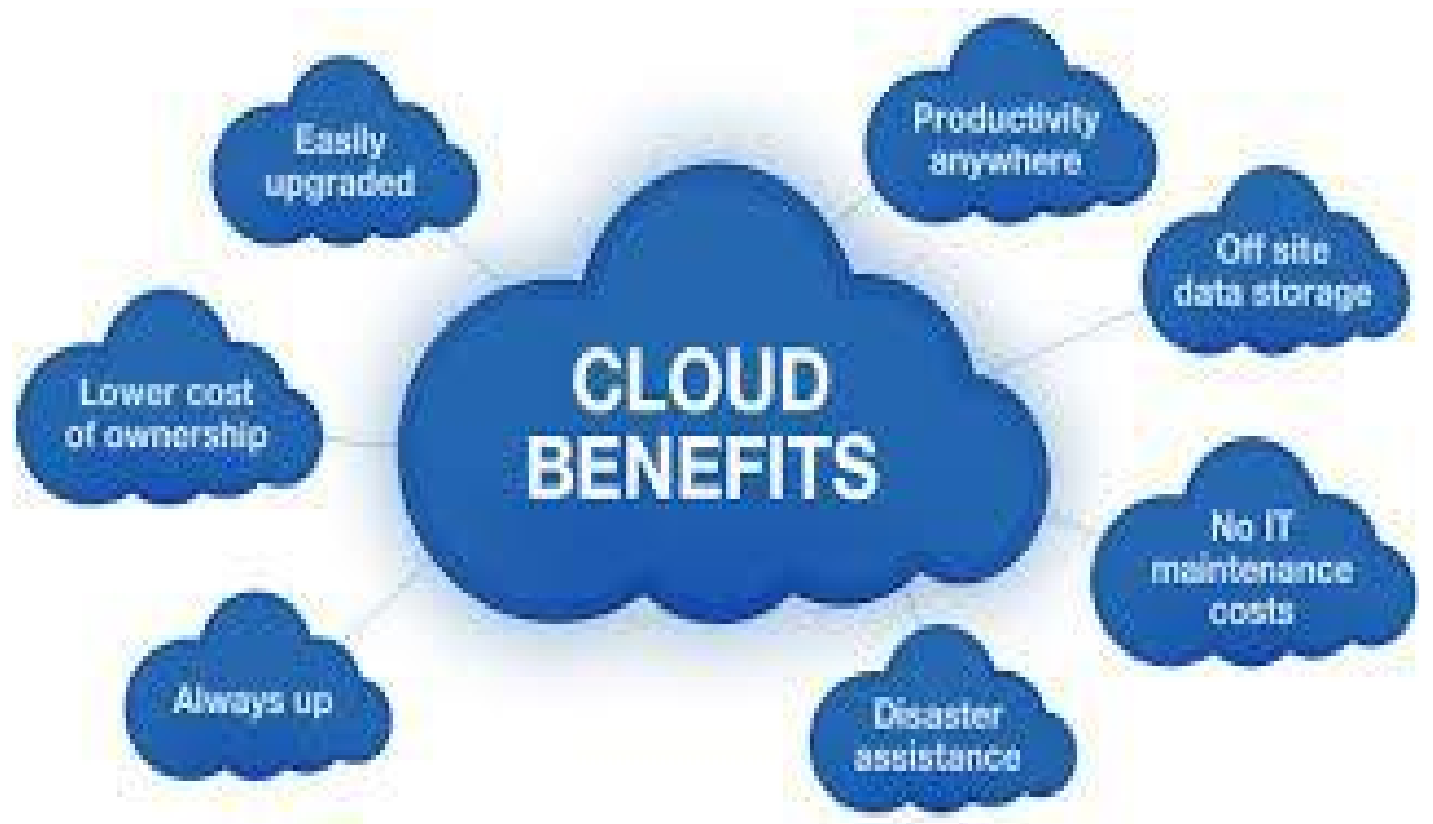

Sumber: www.smartdata.com.

Selain memberikan manfaat, penggunaan cloud computing juga menimbulkan permasalah hukum baru yaitu melanggar privasi data pribadi pelanggan karena aktivitas penyimpanan data yang ditawarkan oleh cloud computing meliputi data-data yang berkaitan dengan kegiatan pelanggan (account activity) sehingga identitas setiap pelanggan yang melakukan akses dan informasi penting lainnya sangat potensial untuk disalahgunakan yang berakibat pada pelanggaran privasi atas data pribadi, terlebih apabila pengguna menyimpan data mereka dalam program-host di hardware orang lain, maka pengguna akan kehilangan kontrol atas informasi pribadi mereka yang sangat sensitif. Dalam kondisi seperti ini, tanggung jawab untuk melindungi informasi itu dari pihak yang tidak bertanggung jawab (misalnya hacker) dan pelanggaran data internal berada di tangan perusahaan penyedia cloud computing. Ada kekhawatiran dari masyarakat ketika data pribadi yang berisi informasi yang sangat penting (sensitif) jatuh ke pihak lain atau perusahaan lain. Pertanyaan selanjutnya adalah apakah data pribadi yang disimpan di suatu tempat dengan menggunakan jasa cloud computing benar-benar aman sebagaimana data yang dilindungi di dalam komputer yang dikendalikan oleh pengguna sendiri dan jaringan. Dengan kata lain, penggunaan cloud computing dapat meningkatkan risiko pelanggaran terhadap data pribadi jika tidak ada aturan yang jelas. 
Kondisi lain yang juga perlu untuk diperhatikan adalah kemungkinan berbagai pihak seperti pemerintah, pelaku bisnis bahkan perorangan akan dapat mengumpulkan dan menyebarkan informasi pribadi tanpa sepengetahuan dari pemilik data. Beberapa perusahaan penyedia cloud computing bahkan dengan sukarela berbagi data sensitif dengan perusahaan pemasaran. Jadi di sini, ada risiko pelanggaran privasi dalam menempatkan data pribadi di tangan orang lain (https://www.privacyrights.org/ar/cloud-computing. htm, diakses tanggal 1 September 2013).

Beberapa contoh kasus pelanggaran telah muncul di Amerika Serikat, diantaranya adalah kasus Amazon Web Services (AWS). AWS adalah perusahaan yang menawarkan berbagai layanan cloud computing yang memungkinkan pengguna untuk menyimpan dan mengelola berbagai jenis data yang mencakup berbagai data pribadi seperti data keuangan, pembayaran dan data pribadi lainnya serta menjanjikan keamanan data pelanggan. Namun demikian, di dalam service level agreement mereka terdapat klausul yang menyatakan bahwa "AWS berhak untuk menolak layanan, menghentikan akun, menghapus, dan mengubah secara sepihak" (http://epic.org/privacy/cloudcomputing/, diakses tanggal 1 Juni 2012). Kasus lain terjadi pada google privacy policy (kebijakan privasi google), yang di dalamnya tertera pernyataan bahwa google memiliki kewenangan untuk mengubah data, mendistribusikan data pribadi tanpa harus meminta izin terlebih dahulu dari si pemilik data (http://epic.org/privacy/cloudcomputing/, diakses tanggal 1 Juni 2012).

Sebuah riset telah dilakukan oleh American Civil Liberties Union of Nortern California (UCLA) tentang pandangan pelanggan jasa cloud computing di Amerika Serikat. Responden dari penelitian ini adalah para mengguna cloud computing. Hasil penelitian menunjukkan sebanyak $49 \%$ responden sangat khawatir data pribadi mereka akan diberikan pada pihak penegak hukum; $63 \%$ merasa khawatir file data pribadi mereka akan disimpan di pihak penyedia jasa; $68 \%$ menyatakan bahwa mereka khawatir data pribadi mereka akan digunakan untuk tujuan pemasaran tanpa persetujuan pemilik data dan hampir $90 \%$ responden sangat khawatir bahwa data pribadi mereka akan diperjualbelikan tanpa izin (UCLA, 2010; Sinta Dewi, 2009: 23).

\section{B. Metode Penelitian}

Penelitian ini adalah yuridis normatif yang bersifat deskriptif analitis. Pengumpulan data dilakukan melalui penelitian kepustakaan dan penelitian lapangan dan tahap penelitian kepustakaan dilakukan untuk mencari data sekunder dengan menggunakan bahan hukum primer, sekunder, dan tertier. Dalam tahap ini juga dilakukan tinjauan kepustakaan terhadap sejumlah peraturan perundang-undangan di beberapa negara yang relevan dengan permasalahan yang diteliti.

\section{Hasil Penelitian dan Pembahasan}

\section{Konsep Perlindungan Data Privasi}

Perkembangan teknologi telah memberikan dampak yang signifikan terhadap kehidupan sosial. Teknologi menawarkan banyak fasilitas terutama berkontribusi terhadap kecepatan konektivitas internet. Secara bersamaan, aksesibilitas terhadap kemajuan teknologi menimbulkan pertanyaan tentang hak individu untuk mempertahankan kerahasiaannya untuk beberapa informasi. Penyebaran informasi yang mudah dan cepat melalui teknologi menciptakan ancaman terhadap privasi dengan memberikan peluang besar bagi pihak yang memiliki akses ke informasi pribadi tersebut.

Sebagai suatu bentuk inovasi, teknologi informasi sekarang ini telah mampu melakukan pengumpulan, penyimpanan, pembagian dan penganalisaan data di mana hal tersebut tidak dapat dibayangkan sebelumnya, sehingga hak privasi telah berkembang untuk merumuskan hak untuk melindungi data pribadi, sebagaimana dinyatakan dalam Pasal 17 Human Rights Committee General Commnt No. 16 on the Rights to Respect of Privacy, Family, Home, and Correspondence, and Protection of Honour and Reputation.

Konsep perlindungan $d$ a $t a$ menginsyaratkan bahwa individu memiliki hak untuk menentukan apakah ia akan bergabung dengan masyarakat kemudian akan membagi atau bertukar data pribadi diantara mereka serta hak untuk menentukan syarat-syarat apakah yang harus dipenuhi untuk melakukan hal tersebut. Hukum perlindungan data secara umum juga mencakup langkahlangkah pengamanan perlindungan dari keamanan data pribadi dan memperbolehkan penggunaannya oleh orang lain sepanjang sesuai dengan syarat yang ditentukan (www. privacyinternational.org, diakses tanggal 15 Oktober 2013).

Konsep hak privasi menjadi populer pada tahun 1890 ketika Samuel Warren dan Louis Brandeis menulis esai berjudul, "The Right to 
Privacy," yang diterbitkan oleh Harvard Law Review. Mereka mengusulkan pengakuan hak individu "right to be let alone" dan juga berpendapat bahwa hak ini harus dilindungi oleh hukum yang ada sebagai bagian dari masalah hak asasi manusia. Dengan demikian, konsep hak privasi telah diakui akan tetapi masih sulit untuk didefinisikan. Privasi, sebagai bagian dari hak asasi manusia, mengidentifikasi perlindungan data pribadi sebagai hak yang penting (Sinta Dewi, 2009: 23). Hak privasi melalui perlindungan data bukan hanya penting namun juga merupakan elemen kunci bagi kebebasan dan harga diri individu. Perlindungan data menjadi pendorong kuat bagi terwujudnya kebebasan politik, spiritual, keagamaan bahkan kegiatan seksual. Hak untuk menentukan nasib sendiri, kebebasan berekspresi dan privasi adalah hak-hak yang penting untuk menjadikan kita sebagai manusia.

Sejumlah instrumen internasional telah mengatur prinsip-prinsip perlindungan data dan banyak aturan-aturan nasional telah memasukannya sebagai bagian dari hukum nasional. The Council of Europe Convention for the Protection of Individuals with regard to Automatic Processing of Personal Data (No. 108), 1981; the Organization for Economic Cooperation and Development Guidelines on the Protection of Privacy and Transborder Data Flows of Personal Data (1980); and the Guidelines for the regulation of computerized personal data files (General Assembly resolution 45/95 and E/CN.4/1990/72) adalah beberapa contoh instrumen internasional yang mengatur perlindungan data.

Perlindungan data juga merupakan hak asasi manusia yang fundamental. Sejumlah negara telah mengakui perlindungan data sebagai hak konstitusional atau dalam bentuk 'habeas data' yakni hak seseorang untuk mendapatkan pengamanan terhadap data yang dimilikinya dan untuk pembenaran ketika ditemukan kesalahan terhadap datanya. Portugal adalah salah satu contoh negara yang telah mengakui perlindungan data sebagai hak konstitusional, yaitu di Pasal 35 Undang-Undang Dasar miliknya. Selain itu, Armenia, Filipina, Timor-Leste, Colombia dan Argentina adalah negara-negara dengan perbedaan sejarah dan budaya yang juga telah mengakui peran perlindungan data dalam memfasilitasi proses demokrasi dan telah menjamin perlindungan data privasi di dalam konstitusi mereka. ASEAN Human
Rights Declaration yang baru saja diadopsi negara-negara ASEAN juga secara jelas mengakui hak atas data privasi (Pasal 21). Dewasa ini, setidaknya ada lebih dari 75 negara telah banyak negara yang undangundangnya mengatur perlindungan data (Graham Greenleaf, 2011).

Beberapa negara memiliki hukum khusus yang melindungi privasi dan data pribadi bagi warga negaranya. Hal ini terutama telah terwujud di negara-negara Eropa dan Amerika Serikat, dimana terdapat hukum yang khusus melindungi privasi dan data pribadi. Namun demikian, konsep privasi yang terdapat di Eropa dan Amerika Serikat memiliki perbedaan karakteristik. Amerika Serikat tidak memiliki regulasi tunggal untuk melindungi privasi dan data yang dapat diterapkan secara khusus. Sementara di Uni Eropa, karena merupakan kawasan terintegrasi, maka perlindungan privasi dan data pribadi diatur oleh kebijakan yang bersifat supranasional dalam bentuk the $E U$ Data Protection Directive.

Sementara itu, konsep dasar perlindungan data pribadi pertama kali muncul sekitar tahun 1960. Selanjutnya tahun 1970, Jerman adalah negara pertama yang memberlakukan peraturan tentang perlindungan data yang kemudian diikuti oleh hukum nasional Swedia pada tahun 1973, Amerika Serikat pada tahun 1974, dan Perancis pada tahun 1978. Konsep perlindungan data sering diperlakukan sebagai bagian dari perlindungan privasi, seperti aturan memberikan perlindungan untuk data pribadi. Perlindungan data pada dasarnya dapat berhubungan secara khusus dengan privasi, dan gagasan itu sendiri dapat diterapkan sebagai kategori yang lebih luas dari privasi. Melihat perlindungan data sebagai bagian dari privasi adalah konsisten dengan pemahaman bahwa privasi sebagai bentuk kerahasiaan, atau hak terhadap pengungkapan maupun penutupan informasi, atau hak untuk membatasi akses individu, atau kontrol informasi yang berkaitan dengan diri seseorang. Namun, terdapat perbedaan penting dalam hal ruang lingkup, tujuan, dan isi dari perlindungan privasi dan data. Perlindungan data secara eksplisit melindungi nilai-nilai yang bukan inti dari privasi seperti syarat untuk pengolahan secara adil, persetujuan, legitimasi, dan non-diskriminasi. Ekspresi dari konsep perlindungan data erat kaitannya dengan hak untuk menghormati kehidupan pribadi dan keluarga. 
Pengaturan perlindungan data merupakan kunci dari permasalahan bisnis dan ekonomi di bidang bisnis informasiintensif di era modern sekarang ini. Praktek bisnis modern saat ini seringkali melibatkan manipulasi data seperti segmentasi data pelanggan, termasuk penambangan data dan pemetikan data, menciptakan profil pelanggan, pengkonsolidasian pengolahan data global, dan proses bisnis lainnya.

\section{Data Privasi dan Penggunaan Cloud Computing (Komputansi Awan)}

Penggunaan jasa cloud computing memiliki potensi resiko yang sangat signifikan yaitu berupa penyalahgunaan data privasi pelanggan termasuk data bisnis yang bersifat rahasia yang dapat dilakukan oleh pemerintah maupun perusahaan penyedia cloud computing (provider). Seringkali, penyedia jasa cloud computing ini pusat datanya berada di luar negeri atau berada di luar yurisdiksi suatu negara (Amerika Serikat merupakan salah satu negara tempat pusat data terbesar di dunia). Oleh sebab itu, menjadi hal yang sulit untuk diselesaikan ketika terjadi penyalahgunaan atas pengelolaan data privasi pelanggan karena selain menyangkut masalah yurisdiksi yang berbeda, juga menyangkut masalah perbedaan pengaturan terkait data privasi antar negara. Apalagi aturan yang berlaku di Amerika Serikat, pihak swasta diberi kebebasan oleh Pemerintah Amerika Serikat untuk mengatur aktivitasnya sendiri terkait pengelolaan data (self regulatory).

Terkait beberapa potensi permasalahan dapat ditimbulkan karena penyalahgunaan pengelolaan data privasi, maka sangat diperlukan pengaturan yang disebut dengan privacy by design. Privacy by design adalah pengaturan pengelolaan data privasi melalui kebijakan privasi atau privacy policy. Privacy policy harus memberikan semua informasi yang dibutukan oleh pihak pelanggan mengenai bagaimana pihak penyedia jasa cloud computing akan mengelola data pribadi pelanggan sehingga pelanggan mengetahui sejauh mana keamanan dan privasi data pribadi mereka akan terjaga termasuk sampai sejauh mana data pribadi mereka akan digunakan untuk kepentingan secondary uses yang biasanya akan diperjualbelikan dan dibagikan kepada perusahaan lainnya. Pelanggan dalam hal ini harus betul-betul memahami resiko menggunakan jasa cloud computing dengan cara membaca dan memahami secara seksama syarat dan ketentuan (terms and condition) yang diberikan oleh pihak penyedia jasa cloud computing sebelum menempatkan informasi yang sangat penting dan apabila pihak pelanggan tidak merasa yakin akan keamanan privasi atas data pribadinya, maka sebaiknya memilih perusahaan lain yang dirasa akan memberi perlindungan yang lebih baik. Selanjutnya konsumen harus menentukan dan mengklasifikasikan data mana yang akan disimpan pada jasa cloud computing karena menyangkut kerahasiaan data pribadi (perusahaan) yang sangat sensitif misalnya. Kemudian, hal yang perlu diperhatikan dan dikaji lebih jauh juga adalah apakah perusahaan penyedia cloud computing memiliki kebijakan atas retensi data. Retensi data berkaitan dengan hak dari penyedia jasa ketika pihak pelanggan menghapus data dari cloud computing. Artinya, ketika pelanggan menghapus data dari cloud computing, apakah pihak penyedia jasa masih diperbolehkan untuk mempertahankan hak atas informasi pelanggan tersebut atau tidak.

3. Konsep Pengaturan Perlindungan Privasi atas Data Pribadi dalam Penggunaan Cloud Computing di Indonesia.

Indonesia sebagai salah satu negara berkembang memiliki jumlah pengguna teknologi dan sistem komunikasi modern yang sangat besar. Namun hingga kini Indonesia belum memiliki hukum yang secara spesifik mengatur mengenai perlindungan privasi dan data. Dengan meningkatnya pemanfaatan teknologi, urgensi untuk mengatasi permasalahan hukum yang terkait dengan perlindungan privasi dan data menjadi meningkat. Hal ini disebabkan karena seringkali hukum yang sudah ada tidak dapat bekerja secara efektif dalam mengikuti perkembangan teknologi. Hukum seringkali berjalan lebih lambat dibandingkan dengan perkembangan masyarakatnya, termasuk juga perkembangan teknologi. Kekosongan hukum ini tentu saja membawa implikasi terhadap perlindungan privasi dan data pribadi. Sebagai anggota dari Asia-Pacific Economic Cooperation (APEC) dan juga sebagai negara calon anggota the Organization for Economic Co-operation and Development (OECD), Indonesia membutuhkan pengaturan terkait perlindungan privasi dan data pribadi 
ini sehingga diharapkan aturan ini dapat memecahkan masalah-masalah yang timbul karena adanya penyalahgunaan pengelolaan data pribadi.

Pengaturan perlindungan data pribadi harus dipertimbangkan sebagai salah satu bidang yang paling penting yang dibutuhkan oleh Indonesia. Ini merupakan isu yang penting dalam komunitas modern karena perlindungan data pribadi akan mempengaruhi cara berkomunikasi dan caracara baru dalam berdagang. Pertumbuhan teknologi memberikan berbagai kesempatan untuk mengumpulkan, menganalisa, dan menyebarkan informasi dengan berbagai cara, oleh sebab itu, masalah perlindungan hukum privasi atas data pribadi menjadi sesuatu hal yang urgen untuk dipikirkan.

Memperhatikan perkembangan internasional dalam pengaturan data privasi, baik yang telah dilakukan oleh banyak negara di dunia maupun oleh organisasiorganisasi internasional, maka Indonesia harus segera mengambil langkah-langkah untuk beradaptasi dengan perkembangan global tersebut. Indonesia harus segera membentuk suatu sistem hukum yang dapat menjamin kepastian hukum namun tetap memperhatikan kesiapan masyarakat dalam menghadapi nilai-nilai baru (Lili Rasjidi, I.B Wyasa Putra, 2003: 187). Nilai baru yang dimaksud di sini adalah kemajuan teknologi yang menghendaki adanya perlindungan privasi atas data pribadi pengguna khususnya dalam menghadapi perkembangan industri cloud computing. Hingga saat ini, Indonesia belum memiliki pengaturan khusus mengenai privasi atas data pribadi. Oleh sebab itu, diperlukan pengaturan hal ini dalam bentuk undang-undang yang secara khusus mengatur perlindungan privasi atas data pribadi, baik yang dilakukan melalui media biasa maupun elektronik (Sinta Dewi, 2009: 51). Selain itu, pembentukan sistem hukum teknologi informasi sangat diperlukan untuk mendorong terjadinya koordinasi dengan undang-undang terkait lainnya dan terciptanya harmonisasi baik dengan prinsip-prinsip internasional maupun dengan pengaturan di negara lain. Jadi penyusunan undang-undang dapat mengakomodasi beberapa kepentingan: pertama, melindungi privasi masyarakat atas informasi pribadi, kedua, memperlancar hubungan perdagangan internasional khususnya e-commerce dengan mengikuti standar pengaturan internasional dengan menyesuaikan dengan keadaan masyarakat Indonesia.

Menurut Lawrence M. Friedman, sistem hukum yang baik akan tercipta melalui beberapa unsur yaitu: (1) struktur; (2) substansi; dan (3) budaya hukum (Lawrence M. Friedman, tahun : 5-19). Pengertian struktur adalah sistem pengadilan. Khusus di dalam membentuk sistem hukum teknologi informasi, perlu dipersiapkan sampai sejauh mana pengadilan di Indonesia dapat menyelesaikan kasus pelanggaran privasi, khususnya yang dilakukan dalam lalu lintas e-commerce. Pengadilan memerlukan suatu pemahaman yang mendalam mengenai pelanggaran privasi dalam e-commerce. Kemampuan dan kemauan para aparat penegak hukum (hakim, jaksa dan polisi) diperlukan agar memahami apa itu pelanggaran privasi khususnya dalam kaitan dengan e-commerce. Hakim dan penegak hukum lainnya harus mampu menyelesaikan kasus-kasus yang muncul sebagai akibat terjadinya perubahan kondisi sosial masyarakat tersebut. Pada akhirnya, dengan adanya struktur yang memadai, diharapkan dapat memberikan kontribusi terhadap pembentukan hukum yang responsif. Hukum responsif adalah hukum yang dapat mengakomodasi dan mengikuti perubahan zaman terutama dalam hal ini berkaitan dengan hukum teknologi infomasi yang selalu cepat berubah.

Lebih jauh, struktur dapat pula berarti bagaimana proses penyusunan undangundang harus dilaksanakan, termasuk melakukan penelitian untuk menggali aspirasi dan kepentingan masyarakat, mengiventarisasi peraturan-peraturan terkait dengan melibatkan sebanyak mungkin stake holder. Sebagai contoh, di Hong Kong. Dalam menyusun Ordonansi, Pemerintah Hong Kong melakukan pendekataan botom up dan top down sehingga semua pihak yang terkait muai dari pemerintah, masyarakat dan industry dilibatkan dalam penyusunan ordonansi ini.

Unsur yang kedua adalah substansi. Substansi berkaitan dengan isi peraturan perundang-undang, yang antara lain meliputi: (1) perbuatan hukum apa saja yang akan diatur; (2) asas-asas yang akan diterapkan baik asas filosofis, yuridis, dan sosiologis; (3) prinsip-prinsip apa saja yang akan menjadi landasan dalam suatu peraturan perundangundangan (termasuk juga prinsip-prinsip yang telah diterapkan secara internasional, 
misalnya fair information principles); dan yang terakhir (4) lembaga mana yang akan mengimplementasikan dan menerapkan sanksi terhadap pelanggar peraturan, sehingga undang-undang yang akan disusun nantinya dapat diterapkan secara efektif.

Terkait dengan budaya hukum, maka suatu sistem hukum dapat tercipta dengan baik sangat ditentukan pula oleh sejauh mana perilaku masyarakat dalam mempersepsikan hukum melalui mekanisme tradisi hukum yang digunakan untuk mengatur kehidupan suatu masyarakat (Lili Rasjidi, I.B Wyasa Putra, tahun: 156-157). Budaya hukum Indonesia memiliki karakteristik bahwa pembentukan hukum dilakukan oleh badan legislatif atas usul dari departemen terkait, melalui masukan dari masyarakat.

Selain pendekatan hukum sebagai mana pendapat Friedman, Lawrence Lessig yang dikutip oleh Sinta Dewi berpendapat bahwa ada pendekatan lain selain pendekatan hukum ang dapat digunakan sebagai salah satu mekanisme perlindungan terhadap aktivitas manusia di dunia maya yaitu melalui mekanisme pasar (market-based solution) (Sinta Dewi, 2009: 25). Mekanisme pasar menawarkan solusi atas problem yang dihadapi untuk mengatur kegiatan ekonomi. Mekanisme ini tidak membutuhkan kekuasaan yang besar untuk menentukan apa yang harus dikonsumsi dan diproduksi. Sebaliknya, tiap individu dibebaskan untuk memilih sendiri apa yang ia butuhkan dan bagaimana memenuhinya. Selanjutnya, menurut Adam Smith, semua diserahkan kepada invisible hand, dan "dunia akan teratur dengan sendirinya”. Dasar dari keputusan para pelaku ekonomi adalah sukarela (voluntary). Hal ini menyebabkan otoritas dan komando tidak lagi terlalu diperlukan. Biaya untuk mempertahankan otoritas pun diminimalkan (Ari A. Perdana, 2001: 2-3). Praktik ini diterapkan dalam pengaturan privasi pada lalu lintas e-commerce di Amerika Serikat dan Singapura. Kedudukan konsumen (dalam hal ini adalah pengguna jasa cloud computing) dalam pendekatan mekanisme pasar dalam lalu lintas e-commerce adalah bahwa konsumen tidak lagi memiliki kemampuan dan kewenangan untuk mengawasi penyebaran informasi pribadinya. Karena oleh itu, pihak penyedia jasa cloud computing dapat mengakses, memproses, dan menyebarluaskan tanpa persetujuan pemilik informasi. Pengaturan ini dikoordinasikan oleh asosiasi industri. Untuk menerapkan prinsip keseimbangan para pihak dalam pengaturan ini, maka pihak industri biasanya menaikkan daya tawar mereka dengan menyatakan bahwa jasa layanan yang mereka kelola terjaga keamanannya (http//www/microsoft, diakses tanggal 10 September 2015). Pengaturan ini juga diterapkan oleh negara Amerika Seikat dan Singapura. Akan tetapi, ternyata di dalam praktiknya, hal ini sulit untuk diterapkan secara efektif karena tidak ada lembaga yang secara khusus dapat mengawasi tindakan pihak penyedia jasa cloud computing (Karim Z. Oussayef, 2008: 125-127; Christopher Millard, 2013: 168-169).

Pendekatan mekanisme pasar ini sebenarnya sangat baik jika dapat diterapkan di Indonesia. Pendekatan ini dapat mendorong pihak penyedia jasa cloud computing turut bertanggung jawab melindungi privasi penggunanya Asalkan di dalam pelaksanaannya, ada suatu lembaga pengawas yang akan menerapkan prinsipprinsip pemanfaatan informasi secara adil dan mempunyai wewenang untuk menjatuhkan sanksi. Dalam hal aktivitas cloud computing, pengaturan pasar atau pihak industri dapat dilakukan melalui pendekatan manajemen resiko cloud computing, yaitu suatu proses untuk mengidentifikasi dan mengukur resiko serta membentuk strategi untuk mengelola resiko melalui sumber daya yang tersedia.

\section{Simpulan}

Konsep pengaturan perlindungan data privasi dalam penggunaan cloud computing yang paling tepat untuk diterapkan di Indonesia adalah melalui pengaturan gabungan atau hybrid. Konsep pengaturan gabungan ini artinya menggabungkan pendekatan hukum dan pendekatan non-hukum yang berupa pendekatan mekanisme pasar.

\section{E. Saran}

a. Perlu dibuat peraturan mengenai perlindungan privasi atas data pribadi agar data pribadi terhindar dari penyalahgunaan dalam hal pengelolaan oleh para pihak yang tidak bertanggung jawab termasuk dari pihak penyedia jasa cloud computing sendiri atau bahkan dari pemerintah. Selain itu, pada saat yang sama, adanya peraturan perlindungan data pribadi diharapkan pula dapat mendorong industri cloud computing di Indonesia. 
b. Pihak konsumen harus diberikan sosialisasi melalui advokasi dan workshop tentang bagaimana mereka mengelola dan menjaga data pribadi mereka karena data pribadi merupakan aset yang penting yang dewasa ini memiliki nilai ekonomi yang tinggi dan berharga.

\section{Daftar Pustaka}

Abdul Raman Saad. 2005. Personal Data \& Privacy Protection. Malaysia: Puddingburn Publishing.

Abu Bakar Munir. 2002. Siti Hajar Mohd Yasin, Privacy \& Data Protection. Malaysia: Sweet \& Maxwell Asia,.

Banisar, 2000, Privacy \& Human Rights, An International Survey of Privacy Laws and Developments. Washington. D.C: Electronic Privacy Information Centre.

Chee, JS, Brian, 2010, dan Curtis, Franklin , Cloud Computing: Technologies and Strategies of the Ubiquitous Data Centre. Florida: CRC Publications.

Lawrence M. Friedman. 2002. American Law. New York: Simon \& Schuster.

Hofstadter and Horowitz. 1964. The Right of Privacy. New York: Central Book Company..

Jayawickrana, Nihal. 2002. The Judicial Application of Human Rights Law, National, Regional and International Jurisprudence. United Kingdom: Cambridge University Press.

Lili Rasjidi dan I.B Wyasa Putra. 2003. Hukum sebagai Suatu Sistem. Bandung: Mandar Maju,. Millard, Christopher (ed), 2013, Cloud Computing Law. United Kingdom: Oxford University Press.. Sinta Dewi.

2009. Cyberlaw: Perlindungan Privasi Atas Informasi Pribadi Dalam E-Commerce Menurut Hukum Internasional. Bandung: Widya Padjadjaran.

Woods, M, Jeanne and Lewis, Hope. 2004. Human Rights and the Global Marketplace. New York: Transnational Publishers Inc..

\section{Artikel Jurnal}

Sinta Dewi. 2015. "Privasi atas Data Pribadi: Perlindungan Hukum dan Bentuk Pengaturan di Indonesia". Jurnal De Jure, Vol. 15 Nomor 2, Juni 2015.

Karim Z. Oussayef. 2008. " Selective Privacy: Facilitating Market-Based Solutions To Data Breaches By Standarizing Internet Privacy Policies”, Boston University Journal of Science and Technology Law, Winter, 2008.

Pound, Roscoe , "Interest of Personality”, Harvard Law Review, Vol. XXVIII, Februari, 1915.

\section{Paper/ Laporan Penelitian}

Ari. A Perdana. 2001. Peranan “Kepentingan” Dalam Mekanisme Pasar dan Penentuan Kebijakan Ekonomi di Indonesia, CSIS Working Paper Series , September 2001.

Balboni, Paolo. 2010. Data Protection and Data Security Issues Related to Cloud Computing in EU, Paper, Tilburg University Legal Studies Working Paper Series, 21 August 2010.

Laporan Penelitian ACLU of Northern California, Januari 2010.

Harmonisasi dan Sinkronisasi Konsepsi Hukum Perlindungan Data dan Informasi Pribadi. Kementrian Pendayagunaan Aparatur Negara. Jakarta, November 2007.

ICT White Paper, Kementrian Informasi dan Komunikasi, 2010.

\section{Internet}

http://netindonesia.net/blogs/ianhutomo/archive/2011/07/14/apa-itu-cloud-computing.aspx, http://www.telkomcloud.com/enterprise/banking/

http://fianka73.blogspot.com/2013/06/di-indonesia-bisnis-cloud-computing.html

https://www.privacyrights.org/ar/cloud-computing.htm

http://epic.org/privacy/cloudcomputing/

http://www.privacyinternational.org. Countries. index.html

http://teknologi.kompasiana.com/terapan/2013/06/20/seluk-beluk-cloud-computing

http://erwindms./2010/06/definisi-cloud-computing.html. 